\title{
Callus Induction and High Frequency Regeneration of Plantlets of Scoparia dulcis L., a Perennial Medicinal Herb, Through Auxiliary Shoot Proliferation
}

\author{
A.K.M. Sayeed Hassan, Farhana Afroz, Laila Shamroze Bari, John \\ Liton Munshi, Miskat Ara Akter Jahan and Rahima Khatun
}

Biological Research Division, BCSIR Laboratories, Dhaka-1205, Bangladesh

Key words: Scoparia dulcis, Medicinal plant, Shoot proliferation, Acclimatization

\begin{abstract}
Green compact nodular callus was observed within three weeks from nodal segments of a perennial medicinal herb Scoparia dulcis L. on MS basal medium supplemented with $1.5 \mathrm{mg} / 1 \mathrm{BAP}+0.2 \mathrm{mg} / \mathrm{I}$ NAA. The callus produced large number of shoots when subcultured on MS with $0.5 \mathrm{mg} / 1 \mathrm{BAP}+0.1 \mathrm{mg} / 1 \mathrm{NAA}$. In vitro raised shoots rooted on half strength of MS with $1.0 \mathrm{mg} / 1 \mathrm{IBA}+1.0 \mathrm{mg} / 1$ NAA. For acclimatization and transplantation, the plantlets in the rooting culture tubes were kept in normal room temperature for seven days before transplanting in pots where plantlets were reared for three weeks. The survival rate of plantlets was found to be $85 \%$. Regenerated plants were morphologically uniform having normal leaf shape and growth.
\end{abstract}

\section{Introduction}

Medicinal plants are of great interest to the researchers in the field of biotechnology as most of the drug industries depend, in part, on plants for the production of pharmaceutical compounds (Chand et al. 1997). Among the world's 25 best selling pharmaceutical medicines, 12 are plant derived (O'Neill and Lewis 1993). Scoparia dulcis L. commonly known as 'Chinigura' belongs to Scrophulariaceae, a small erect, slender, rigid, perennial herb with three serratemargined, ovate-elliptic leaves at each node, small white, axillary, solitary flowers and small coriander-like fruits, grows as a common weed in all areas of Bangladesh (Ghani 1998). Ten Scoparia species were noted from Argentina (Escandon et al. 2005). Among them Scoparia dulcis is abundandly distributed in many tropical countries like India and Bangladesh. Leaf of Scoparia dulcis is used as a cure for gastric ulcer and weakness. Infusion of leaves is used in fever, cough, bronchitis, diarrhoea and dysentery and as a diuretic and gargle for toothache. Decoction of the leaves is useful in curing gavel and kidney problems. 
The plant is also used in diabetes and to stop bleeding (Ghani 1998). All parts of the plant are useful as emetic. An infusion of seeds obtained by soaking them in water overnight is a cooling drink. The plant is used as cattle fodder. An antidiabetic compound, amellin, has been reported in the leaf and stem of the fresh green plant. Oral administration of amellin is reported to relieve symptoms of glycosuria, reduce hyperglycaemia and increase RBC count. It has also been found to be helpful in anaemia, albuminuria, ketonuria, retinitis and other complication associated with Diabetes mellitus. Unlike insulin, amellin does not cause blood sugar levels to drop below normal and reduction of both blood and urine sugar occur gradually. Amellin is reported to raise the lowered alkali in diabetics, and reduce iron content of serum and acetone bodies in blood.

In accordance with the World Health Organization, more than 20,000 plant species are used medicinally, while $80 \%$ of the world's total population rely chiefly on herbal traditional medicine as their primary health care; even in the developed countries like USA, plants are the source of ingredients in one-forth of the prescriptions delivered by pharmacists (Phillipson 1990). However, with the increasing use of medicinal plants in many countries, and with the accelerating destruction of natural resources in the tropics, it has become clear that the exploitation of medicinal plants must be accompanied by conservation measures. Otherwise these plants become depleted as resources or may even face extinction (Hamann 1991). Thus it is important to regenerate the affected plants artificially, which having beneficial effects on the ecosystems. Particularly when conventional propagation methods lead to unsatisfactory results, plant tissue culture techniques may be a valuable tool for the production of large amount of genetically identical plantlets for further field culture as conservation (Wawrosch and Kopp 1999).

In recent years, there has been an increased interest in in vitro culture techniques which offer a viable tool for mass multiplication and germplasm conservation of rare, endangered and threatened medicinal plants (Ajithkumar and Seeni 1998, Prakash et al. 1999). Commercial exploitation and elimination of natural habits consequent to urbanization has led to gradual extinction of several medicinal plants. Micropropagation is an effective approach to conserve such germplasm. Further, genetic improvement is another approach to augment drugyielding capacity of the plant (Tejavathi and Shailaja 1999). In vitro propagation has proven as a potential technology for mass scale production of medicinal plant species (Lui and Li 2001, Wawrosch et al. 2001, Martin 2002, 2003; Azad et al. 2005, Faisal et al. 2003, Hassan and Roy 2005). Therefore, it is important to develop an efficient micropropagation technique for Scoparia dulcis to rapidly disseminate superior clones once they are identified. Tissue culture technique can play an important role in the clonal propagation of elite clones and 
germplasm conservation of this medicinal herb. There have been a few reports to date on in vitro propagation of Scoparia dulcis using nodal explants derived callus tissue. However, in Bangladesh, there is no report on the establishment of a micropropagation protocol through callus culture for Scoparia dulcis. The present study was, therefore, undertaken to develop a protocol for in vitro propagation of this important medicinal herb through callus culture.

\section{Materials and Methods}

The experiment was conducted at Biological Research Division in Bangladesh Council of Scientific and Industrial Research (BCSIR), Dhaka. Healthy and profusely growing vine of Scoparia dulcis L. was collected from BCSIR campus, Dhaka and used as source of explants. Shoot tips and nodal segments with a single axillary bud were used for this purpose. The explants were washed thoroughly under running tap water, pre-soaked in liquid detergent for about 30 min, wiped with cotton and dipped in $70 \%$ (v/v) ethanol for $1 \mathrm{~min}$. They were then surface sterilized with $0.1 \%(\mathrm{w} / \mathrm{v})$ mercuric chloride for $8 \mathrm{~min}$, followed by five rinses with sterile distilled water in front of a laminar air flow cabinet. The surface sterilized explants were sized to $1-1.5 \mathrm{~cm}$ length containing a single node with an axillary bud or a shoot tip with an apical bud. The explants were placed vertically on the culture medium. The new shoots induced from the in vitro cultures were further used as an explants for adventitious shoot regeneration.

MS basal medium was used for shoot proliferation and adventitious shoot regeneration and half strength of MS was used for in vitro rooting. All media were supplemented with $30 \mathrm{~g} / 1$ sucrose, $7 \mathrm{~g} / 1$ agar (Difco) and dispensed into 15 $\times 150 \mathrm{~mm}$ culture tubes and $250 \mathrm{ml}$ conical flasks. The $\mathrm{pH}$ of the media was adjusted to 5.8 before autoclaving at $121^{\circ} \mathrm{C}$ for $20 \mathrm{~min}$. The cultures were incubated for a $16 \mathrm{~h}$ photoperiod at $24 \pm 2^{\circ} \mathrm{C}$ under a fluorescent light.

Shoot proliferation from shoot tips and nodal explants was obtained in two separate sets of experiments. In the first experiment $0-2.5 \mathrm{mg} / 1 \mathrm{BA}$ and $0-2.5$ $\mathrm{mg} / \mathrm{Kn}$ were supplemented into MS to select the their best concentration for shoot induction. In the second set, combination of BA - NAA (0 - $2.5 \mathrm{mg} / \mathrm{l})$ and BA - IAA (0 - $2.5 \mathrm{mg} / \mathrm{l})$ were assessed for shoot multiplication. Number of new shoot proliferation of each culture was recorded after every week of inoculation.

For in vitro rooting, individual shoots $(3-5 \mathrm{~cm})$ were excised from the proliferated shoot cultures and implanted onto half strength of MS with different concentrations and combinations of NAA, IBA and IAA.

The rooted plants were taken out from the culture tubes, washed to remove agar gel adhered to the roots and transplanted to plastic pots with soil and compost $(1: 1)$ for hardening. The plantlets were kept in a polychamber at $80 \%$ 
relative humidity, $32 \pm 2{ }^{\circ} \mathrm{C}$ under a $12 \mathrm{~h}$ photoperiod for acclimation. Established plants were transplanted in earthen pots under natural conditions and the survival rate was recorded.

\section{Results and Discussion}

Within seven to 15 days of culture callus was formed at the cut surface of nodal explant on MS supplemented with $0.5-2.0 \mathrm{mg} / 1 \mathrm{BAP}$ either alone or in combination with $0.1-0.5 \mathrm{mg} / 1$ NAA or IAA (Table 1$)$. Maximum $(82.2 \%)$ callus was observed on MS with $1.5 \mathrm{mg} / 1 \mathrm{BAP}+0.5 \mathrm{mg} / 1$ NAA after two weeks (Fig. la). In this combination deep green compact and nodular callus developed after four weeks of culture (Fig. 1b). Initiation of shoot buds was observed from the same callus when subcultured on MS $+0.5 \mathrm{mg} / 1 \mathrm{BAP}+0.1 \mathrm{mg} / 1 \mathrm{NAA}$ after six weeks (Fig. 1c). Proliferation of callus along with profuse shoot bud formation on the same medium was obtained after eight weeks (Fig. 1d). Shoot differentiation and profuse shoot formation were found to be best from callus on the same medium after ten and 12 weeks of culture (Fig. 1e, f). However, BAP with NAA was found to be more effective than BAP with IAA for callus induction (Table 1). According to Preece et al. (1991), callus forms frequently at the basal cut ends of nodal explants on cytokinin-enriched medium in species exhibiting strong apical dominance.

The highest number of shoots was $29.2 \pm 5.44$ per culture and length of shoot was $7.2 \pm 0.61$ developed on MS with $0.5 \mathrm{mg} / 1 \mathrm{BAP}+0.1 \mathrm{mg} / 1$ NAA (Table 1, Fig. 1f). There were differences in regeneration frequencies, number and length of shoots per culture in different combinations. As stated by Martin (2002) the high morphogenic efficiency of nodal segments derived callus may be due to the presence of some internal components from the pre-existing axillary buds that are essential for induction of caulogenesis. Shoot buds developed and elongated from callus culture on the same medium. This continued in two subsequent subcultures made up of identical constituents at an interval of 15 days. Shoot regeneration via a callus phase was the simplest way to induce somaclonal variation and thus pave the way for improvement of the species (Thorpe et al. 1991). Such indirect organogenesis was reported in many medicinal plant species including Asparagus cooperi (Ghosh and Sen 1989), Bixa orellana (Sha et al. 2002), Plumbago zeylanica (Das and Rout 2002), Holostema ada-kodien (Martin 2002), Ananas comosus (Akbar et al. 2003), Rotula aquatica (Martin 2003), Gloriosa superba (Sivakumer et al. 2003), Phellodendron amurense (Azad et al. 2005) and Abrus precatorius (Biswas et a1. 2007). 
Rooting in regenerated shoots $(85.2 \%)$ of Scoparia dulcis was obtained when the excised shoots were cultured individually on root induction medium consisting of half strength of MS with $0.5 \mathrm{mg} / 1 \mathrm{IBA}+0.5 \mathrm{mg} / 1 \mathrm{NAA}$ (Table 2).
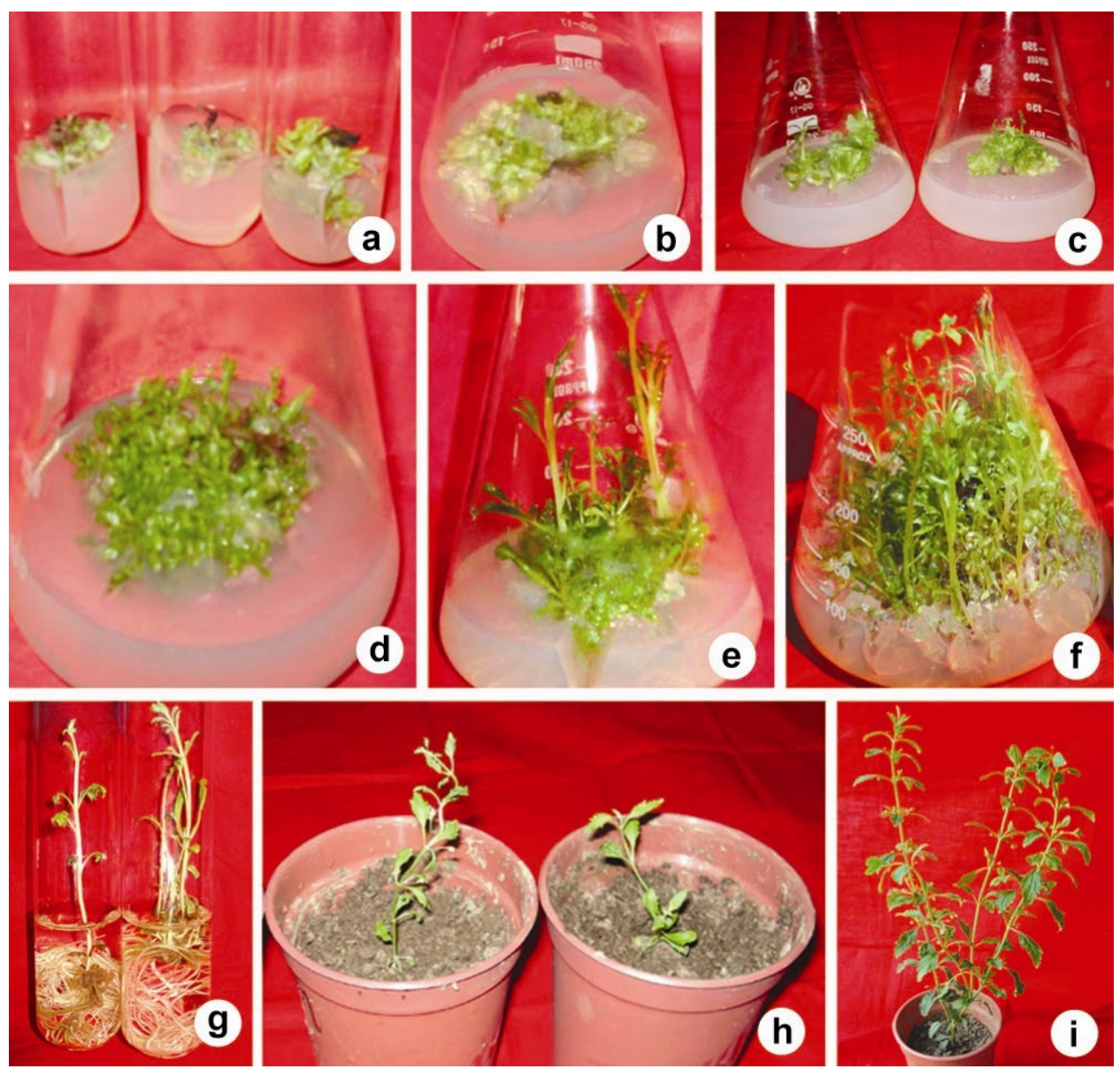

Fig. 1. In vitro plant regeneration from callus culture of Scoparia dulcis. (a) Callus formation started at the cut surface of nodal explant. (b) Deep green nodular callus expansion on the same medium after four weeks of culture. (c) Initiation of shoot buds from the same callus after six weeks of culture. (d) Proliferation of callus along with profuse shoot bud formation on the same medium after eight weeks of culture. (e) Shoot differentiation from callus on the same medium after ten weeks of culture. (f) Profuse shoot differentiation from callus on the same medium after 12 weeks of culture. (g) Rooting of in vitro regenerated shoots in half strength of MS in eight weeks. (h) Acclimatized regenerated plants of one month old. (i) Acclimatized regenerated plant of three months old.

Roots initiated by third weeks of culture. In this medium the highest per cent (85.2) of roots responded and their maximum number was $13.4 \pm 0.24$ at the cut end of microshoots within four weeks of culture. Use of auxins singly or in 
combination for rooting was also reported by different authors (Sahoo and Chand 1998, Ajithkumar and Seeni 1998, Rai 2002, Baskaran and Jayabalan 2005, Sivakumar and Krishnamurthy 2000, Hassan and Roy 2005, Rahman et al. 2006, Baksha et al. 2007).

Table 1. Effect of different concentrations and combinations of growth regulators on MS for the adventitious shoot regeneration from the nodal callus of Scoparia dulcis.

\begin{tabular}{|c|c|c|c|c|c|}
\hline \multicolumn{3}{|c|}{$\begin{array}{l}\text { Growth regulators } \\
\qquad(\mathrm{mg} / \mathrm{l})\end{array}$} & \multirow{2}{*}{$\begin{array}{c}\% \text { of explants } \\
\text { producing callus } \\
\text { with shoots }\end{array}$} & \multirow{2}{*}{$\begin{array}{c}\text { Mean No. of } \\
\text { shoots/culture } \\
(\text { Mean } \pm S E)\end{array}$} & \multirow{2}{*}{$\begin{array}{l}\text { Mean length of } \\
\text { shoots }(\mathrm{cm}) \\
(\text { Mean } \pm \text { SE) }\end{array}$} \\
\hline BAP & NAA & IAA & & & \\
\hline 0.5 & & & 24.2 & $9.6 \pm 0.51$ & $2.6 \pm 0.40$ \\
\hline 1.0 & & & 33.8 & $9.4 \pm 0.51$ & $2.2 \pm 0.20$ \\
\hline 1.5 & & & 46.8 & $10.6 \pm 0.40$ & $2.6 \pm 0.40$ \\
\hline 2.0 & & & 40.4 & $8.8 \pm 0.37$ & $2.2 \pm 0.20$ \\
\hline 0.5 & 0.1 & & 81.2 & $29.2 \pm 1.74$ & $7.2 \pm 0.58$ \\
\hline 1.0 & 0.2 & & 70.6 & $11.6 \pm 0.51$ & $2.8 \pm 0.37$ \\
\hline 1.5 & 0.5 & & 82.2 & $14.4 \pm 1.29$ & $3.2 \pm 0.37$ \\
\hline 2.0 & 0.5 & & 67.2 & $13.0 \pm 0.71$ & $2.6 \pm 0.24$ \\
\hline 0.5 & & 0.1 & 74.0 & $23.4 \pm 0.75$ & $6.2 \pm 0.37$ \\
\hline 1.0 & & 0.2 & 68.8 & $10.8 \pm 0.37$ & $3.4 \pm 0.51$ \\
\hline 1.5 & & 0.5 & 77.8 & $13.4 \pm 0.75$ & $3.6 \pm 0.51$ \\
\hline 2.0 & & 0.5 & 64.4 & $11.8 \pm 0.37$ & $2.8 \pm 0.37$ \\
\hline
\end{tabular}

Data were recorded two months after inoculation. Results are mean \pm SE of three experiments with 15 replications.

After eight weeks (Fig. $1 \mathrm{~g}$ ) the rooted shoots were transferred to pots. None of the plantlets survived when directly transferred from rooting medium to the pot under natural conditions. About 85 per cent of the transplanted plants of Scoparia dulcis survived if the plants in the rooting culture tubes were kept in normal room temperature for seven days before transplantation in pots and reared for three weeks. The plantlets were reared under semi-controlled temperature $\left(30 \pm 2^{\circ} \mathrm{C}\right)$ and light $(2000 \mathrm{lux})$ in a chamber with 80 per cent humidity. During this period of acclimation shoots elongated, leaves expanded and turned deep green and healthier (Fig. 1h ).

After three weeks, plants were transferred to an open place and gradually acclimated to outdoor conditions, where 85 per cent plants survived. The technique described here appears to be a promising one of propagation of Scoparia dulcis. As the potentiality of shoot multiplication from callus continued for a long time, regenerates may be characterized by somaclonal variation. Several species of Dubosia (Lin and Griffm 1992), Cuphea (Millam et al. 1997), Amaranthus (Bennici et al. 1997), Salvia (Liu et al. 2000) and Ananas comosus (Akbar 2003) produced regenerates through callus-mediated adventitious shoot differentiation. Such regenerates may prove to be a potential source of 
somaclonal variants, giving birth to traits of agronomic importance. The regenerated plants of Scoparia dulcis are currently being screened for agronomically useful genetic variants.

Table 2. Effect of half strength MS with different concentrations of auxin on root formation in regenerated shoots of Scoparia dulcis.

\begin{tabular}{|c|c|c|c|c|c|}
\hline \multicolumn{3}{|c|}{$\begin{array}{c}\text { Growth regulators } \\
(\mathrm{mg} / \mathrm{l})\end{array}$} & \multirow{2}{*}{$\begin{array}{l}\% \text { of shoots } \\
\text { producing roots }\end{array}$} & \multirow{2}{*}{$\begin{array}{l}\text { Mean no. of } \\
\text { roots/shoot } \\
(\text { Mean } \pm \text { SE) }\end{array}$} & \multirow{2}{*}{$\begin{array}{l}\text { Average length } \\
\text { (cm) of roots } \\
\text { (Mean } \pm \text { SE) }\end{array}$} \\
\hline IBA & NAA & IAA & & & \\
\hline 0.5 & & & 67.2 & $11.8 \pm 0.37$ & $2.3 \pm 0.20$ \\
\hline 0.75 & & & 63.2 & $9.2 \pm 0.37$ & $2.6 \pm 0.29$ \\
\hline 1.0 & & & 57.8 & $9.6 \pm 0.51$ & $2.3 \pm 0.20$ \\
\hline & 0.5 & & 71.0 & $9.2 \pm 0.37$ & $2.4 \pm 0.19$ \\
\hline & 0.75 & & 54.2 & $8.0 \pm 0.71$ & $2.3 \pm 0.20$ \\
\hline & 1.0 & & 59.4 & $8.2 \pm 0.37$ & $1.9 \pm 0.10$ \\
\hline 0.5 & 0.5 & & 85.2 & $13.4 \pm 0.24$ & $3.5 \pm 0.22$ \\
\hline 1.0 & 1.0 & & 82.0 & $11.8 \pm 0.37$ & $2.6 \pm 0.19$ \\
\hline 0.5 & & 0.5 & 65.2 & $9.8 \pm 0.58$ & $2.0 \pm 0.16$ \\
\hline 1.0 & & 1.0 & 61.4 & $8.6 \pm 0.51$ & $2.1 \pm 0.24$ \\
\hline 0.5 & 0.5 & 0.5 & 62.6 & $9.2 \pm 0.73$ & $2.0 \pm 0.16$ \\
\hline 1.0 & 1.0 & 1.0 & 54.4 & $9.6 \pm 0.51$ & $1.6 \pm 0.19$ \\
\hline
\end{tabular}

Data were recorded after four weeks of culture. Results are mean \pm SE of 15 replications.

\section{Acknowledgement}

The authors are indebted to Professor Shyamal K. Roy, Department of Botany, Jahangimagar University, Savar, Dhaka. They are also grateful to the Director, BCSIR Laboratories, Dhaka for his kind help and encouragement during the study.

\section{References}

Ajithkumar D and Seeni S (1998). Rapid Clonal Multiplication through in vitro Axillary Shoot Proliferation of Aegle mannelos (L.) Corr., a Medicinal Tree. Plant Cell Rep. 17: 422-426.

Akbar MA, Karmakar BK and Roy SK (2003). Callus induction and high-frequency plant regeneration of pineapple (Annas comosus (L.) Merr.). Plant Tissue Cult. and Biotech. 13(2) : 109-116.

Azad MAK, Yokota S, Ohkubo T, Andoh Y, Yahara S and Yoshizawa N (2005). In vitro regeneration of the medicinal woody plant Phellodendron amurense Rupr. Through excised leaves. Plant Cell Tiss. Orga. Cult. $80: 43-50$.

Baskaran P and Jayabalan N (2005), An efficient micropropagation system for Eclipta alba, a valuable medicinal herb. In Vitro Cell. Dev. Biol. Plant. 41: 532539.

Babha R, Jahan MAA, Khatun $\mathbf{R}$ and Munshi JL (2007). In vitro rapid clonal propagation of Rauvolfia serpentina (Linn.) Benth. Bangladesh J. Ind. Res. 42(1): 37-44. 
Bennici A, Grifoni T, Schiff S and Bovelli R (1997). Studies on callus growth and morphogenesis in several species and line of Amaranthus. Plant Cell Tiss. Orga. Cult. 49: 29-33.

Biswas A, Roy M, Miah MAD and Bhadra SK (2007). In vitro propagation of Abrus precatorius L., a rare medicinal plant of Chittagong Hill Tracts. Plant Tissue Cult. and Biotech. 17(1): 59-64.

Chand S, Sahrawat AK and Prakash DVSSR (1997). In vitro culture of Pimpinella anisum L. (Anise) J. Pl. Biochem. Biotech. 6: 1-5.

Das G and Rout GR (2002). Plant regeneration through somatic embryogenesis in leaf derived callus of Plumbago indica. Biologia Plantarum 45(2): 299-302.

Escandon AS, Miyajima I, Alderete M, Hagiwara JC, Facciuto G, Mata D and Soto SM (2005). Wild ornamental germplasm exploration and domestication based on biotechnological approaches. In vitro colchicine treatment to obtain a new cultivar of Scoparia montevidiensis. Electron Journal of Biotechnology 8(2): 1-8.

Faisal M, Ahmad N and Anis M (2003). Shoot multiplication in Rauvolfia tetraphylla L. using thidiazuron. Plant Cell Tiss. Organ. Cult. 80: 187-190.

Ghani A (1998). Medicinal Plants of Bangladesh with Chemical Constituents and Uses, Asiatic Society of Bangladesh, Dhaka, pp 373.

Ghosh B and Sen S (1989). Somatic embryos in Asparagus cooperi Baker. Curr. Sci. 58: 256-257.

Hamann O (1991). The joint IUCN-WWF plant conservation program and its interests in Medicinal plants. In: The Conservation of Medicinal Plants, Akerele Heywood V and Synge H (Eds.) Cambridge University Press, Cambridge, pp. 1322.

Hassan AKM and Roy SK (2005). Micropropagation of Gloriosa superba L. Through High Frequency Shoot Proliferation. Plant Tissue Cult. and Biotech. 15(1): 67-74.

Lin GD and Griffin WJ (1992). Organogenesis and a general procedure for plant regeneration from callus culture of a commercial Dubosia hybrid (D. leiehhardtii $\times D$. myoporoides). Plant Cell Rep. 11: 207-210.

Liu W, Chilcott C, Reich R and Hellmann GM (2000). Regeneration of Salvia selarea via organogenesis. In vitro Cell Dev. Biol. Plant. 36: 201-206.

Lui Z and Li Z (2001). Micropropagation of Camptotheea aeuminata Decaisne from axillary buds, shoot tips and seed embryos in tissue culture system. In Vitro Cell Dev. Biol. Plant. 37: 84-88.

Martin KP (2002). Rapid propagation of Holostema ada-kodien Schult. a rare medicinal plant, through axillary bud multiplication and indirect organogenesis. Plant Cell Rep. 21: 112-117.

Martin KP (2003). Plant regeneration through somatic embryogenesis on Holostema adakodien Schult., a rare medicinal plant. Plant Cell Tiss. Orga. Cult. 72: 79-82.

Millam S, Mitchell SM, Moscheni E and Lyon JE (1997). The establishment and regeneration of a range of Cuphea germplasm in vitro. Plant Cell Tiss. Orga. Cult. 48: 143-146.

'O' Neill M and Lewis A (1993). Human medicinal agents from plants. In : Kinghorn AD Balandrin MF, ACS Sysmposium Series 534, Washington, DC. pp. 48. 
Phillipson JD (1990). In: Secondary Products from Plant Tissue Culture Charlwood BV and Rhodes MJC (Eds.), Clarendon Press, Oxford. pp. 1-21.

Prakash E, Sha Valli Khan PS, Sairam Reddy P and Rao KR (1999). Regeneration of plants from seed-derived callus of Hybanthus enneaspermus L. Muell., a rare ethnobotanical herb. Plant Cell Rep. 18: 873-878.

Preece JE, Hutterman CA, Ashby WC and Roth PL (1991). Micro and cutting propagation of silver maple. 1. Results with adult and juvenile propagules. J. Am. Soc. Hort. Sci. 116: 142-148.

Rahman SMR, Afroz F, Sultana K, Sen PK and Ali MR (2006). Effect of growth regulators and state of medium on micropropagation of Adhatoda vasica (Nees.) Khulna University Studies, Special Issue (1st Research Cell Conference): 55-59.

Rai VR (2002). Rapid clonal propagation of Nothapodytes foetida (Weight) Sleumera threatened medicinal tree. In Vitro Cell Dev. Biol. Plant 38: 347-351.

Sahoo Y and Chand PK (1998). Micropropagation of Vitex nigundo L., a woody aromatic medicinal shrub, through high frequency axillary shoot proliferation. Plant Cell Rep. 18: 301-307.

Sha Yalli Khan PS, Prakash E and Rao KR (2002). Callus induction plantlet regeneration in Bixa orellana L., an annatto-yielding tree. In vitro Cell. Dev. Biol. Plant. 38: 186-190.

Sivakumar G and Krishnamurthy KV (2000). Micropropagation of Gloriosa superba L., an endangered species of Asia and Africa. Curr. Sci. 78(1): 3032.

Sivakumar G, Krishnamurthy KY and Rajendran TD (2003). Embryogenesis and plant regeneration from leaf tissue of Gloriosa superba L. Planta Med. 69: 479481.

Tejavathi DH and Shailaja KS (1999) Regeneration of Plants from the Cultures of Bacopa monnieri (L.) Pennell. Phytomorphology 49(4): 447-452.

Thorpe TA, Harvey IS and Kumar PP (1991). Application of micropropagation in forestry. In: Micropropagation, technology and application, Debergh PC and Zimmerman RH (Eds), Kluwer, Dordrecht, pp. 311-336.

Wawrosch C and Kopp B (1999). Application of plant tissue culture in protection and domestication of rare and endangered medicinal plants. In Vitro Cell. Dev. Biol. Plant. 35: 180-181.

Wawrosch C, Malia RR and Kopp B (2001). Clonal propagation of Lilium nepalense D. Don, a threatened medicinal plants of Nepal. Plant Cell Rep. 10: 457-460. 